\title{
PENGARUH PEMBIAYAAN MUSYARAKAH TERHADAP PENDAPATAN BAGI HASIL PADA TIGA BANK UMUM SYARIAH
}

\author{
Tanti Aulyza Putri ${ }^{1}$, \\ Sulaeman', \\ Tina Kartini ${ }^{3}$ \\ Fakultas Ekonomi, Universitas Muhammadiyah Sukabumi \\ Email: Putriaulyza17@gmail.com \\ Fakultas Ekonomi, Universitas Muhammadiyah Sukabumi \\ Email: sulaeman1342@ummi.ac.id \\ Fakultas Ekonomi, Universitas Muhammadiyah Sukabumi \\ Email: tinakartini386@ummi.ac.id
}

\begin{abstract}
Abstrak
Pendapatan bagi hasil pada suatu bank syariah dapat dihasilkan dari pembiayaan berbasis bagi hasil, salah satunya yaitu pembiayaan musyarakah. Semakin banyaknya minat masyarakat pada pembiayaan musyarakah, bertambah pula pendapatan bagi hasilnya. Tujuan dari penelitian ini untuk mengetahui pengaruh pembiayaan musyarakah terhadap pendapatan bagi hasil secara simultan dan signifikan. Metode yang digunakan pada penelitian ini yaitu kuantitatif dengan jenis asosiatif. Teknik pengumpulan data yaitu data sekunder dengan sampel berupa dokumen laporan keuangan triwulan dari 3 bank umum syariah di indonesia dan juga melakukan studi kepustakaan. Populasi dan sampel yang diambil dalam penelitian ini sebanyak 36 meliputi laporan keuangan pertriwulan pada 3 bank umum syariah di indonesia yaitu bank muamalat indonesia, bank bni syariah, bank bri syariah. Teknik analisis data menggunakan uji normalitas, uji heteroskedastisitas, uji regresi linier sederhana, uji $t$, dan uji koefisien determinasi. Hasil penelitian menggunakan SPSS 25 dapat disimpulkan bahwa pembiayaan musyarakah berpengaruh positif dan signifikan terhadap pendapatan bagi hasil dengan nilai signifikansi nya sebesar 0,000 < 0,05 dan berdasarkan hal tersebut Ha diterima Ho ditolak.
\end{abstract}

Kata kunci: Pembiayaan Musyarakah, Pendapatan Bagi Hasil

\section{PENDAHULUAN}

Perkembangan keuangan berbasis syariah di Indonesia saat ini mengalami pertumbuhan yang cukup pesat. Ditandai dengan banyaknya lembaga keuangan bank maupun non bank yang menggunakan prinsip syariah. Keuangan berbasis syariah ini bertujuan untuk mendorong pertumbuhan ekonomi masyarakat dengan penerapan dilaksanakan sesuai dengan dasar hukum syariat islam agar terhindar dari ketidakadilan.

Perbankan Syariah tidak menerapkan sistem bunga dalam aktivitas perbankannya. Bunga dianggap bagian dari riba dan haram dalam hukum agama islam. Sebagai gantinya, perbankan yang berlandaskan Syariah ini menerapkan sistem bagi hasil atau nisbah yang menurut islam sah untuk dilakukan. Salah satunya yaitu pembiayaan musyarakah. Akad musyarakah merupakan akad kerjasama antara dua pihak atau lebih untuk suatu usaha tertentu dimana masing-masing pihak memberikan kontribusi dana dengan kesepakatan bahwa keuntungan dan risiko akan ditanggung bersama sesuai dengan kesepakatan.

(Sabrina \& Majid, 2019) Pembiayaan musyarakah memiliki tingkat risiko, risiko terjadi apabila tidak transparansi dalam melakukan pembiayaan ini. Maka dari itu, prinsip transparansi harus diterapkan agar tidak terjadi kerugian diantara kedua belah pihak dan juga meminimalisir itikad kurang baik yang kemungkinan terjadi di kemudian hari.

Resiko dalam pembiayaan musyarakah harus dapat ditanggulangi oleh bank, bila sewaktuwaktu terjadi kerugian akibat kelalaian yang terjadi. Baik yang tidak disengaja maupun disengaja oleh oleh kedua belah pihak selaku pelaku akad pembiayaan tersebut.

Menurut teori (Triana, 2019) berkesimpulan pendapatan bagi hasil diperoleh dari pembiayaan musyarakah dan pembiayaan mudharabah. Hal itu menunjukkan bahwa pembiayaan musyarakah menjadi salah satu faktor untuk menghasilkan pendapatan bagi hasil pada bank selain pembiayaan mudharabah. Maka dengan teori ini, penulis tertarik untuk melihat pengaruh pembiayaan musyarakah terhadap pendapatan bagi hasil. 
Pembiayaan musyarakah diharapkan dapat meningkatkan pendapatan bagi hasil pada bank. Karena pada dasarnya sistem utama yang digunakan pada bank syariah ini yaitu konsep bagi hasil, dimana konsep ini diharapkan dapat memudahkan seseorang. Dimana ada orang yang memiliki harta yang berlebih tetapi tidak mampu untuk mengelolanya, dan ada sebagian orang yang tidak memiliki harta tetapi memiliki keinginan dan bakat atau keterampilan dalam mengelola sesuatu agar menghasilkan sesuatu yang bermanfaat bagi banyak orang.

Penulis mengambil 3 bank umum syariah untuk dijadikan referensi penelitian, sebagai perbandingan antara bank muamalat, bank bni syariah, bank bri syariah. Karena dapat diketahui bank mualamat indonesia merupakan bank syariah pertama di Indonesia, lalu bank bri syariah dan bank bni syariah yang berdiri setelah bank muamalat dan mengalami kemajuan yang cukup pesat. Ketiga bank ini digunakan sebagai pembanding oleh penulis untuk melihat perkembangan pembiayaan musyarakah dan pendapatan bagi hasil nya.

\section{Tabel 1}

Data Pembiayaan Musyarakah dan Pendapatan Bagi Hasil

\begin{tabular}{|c|c|c|}
\hline Nama Bank & $\begin{array}{l}\text { Pembiayaan } \\
\text { Musyarakah }\end{array}$ & $\begin{array}{l}\text { Pendapatan Bagi } \\
\text { Hasil }\end{array}$ \\
\hline \multirow{3}{*}{$\begin{array}{l}\text { Bank Muamalat } \\
\text { Indonesia }\end{array}$} & Rp20.125.269 & Rp1.734.277 \\
\hline & Rp19.160.884 & Rp1.783.921 \\
\hline & Rp15.856.148 & Rp1.450.097 \\
\hline \multirow{3}{*}{ Bank BRI Syariah } & Rp5.185.890 & Rp693.611 \\
\hline & Rp5.447.998 & Rp670.205 \\
\hline & Rp7.406.955 & Rp724.570 \\
\hline \multirow{3}{*}{ Bank BNI Syariah } & Rp2.907.463 & Rp418.551 \\
\hline & Rp4.444.876 & Rp475.310 \\
\hline & Rp7.106.936 & Rp622.064 \\
\hline
\end{tabular}

Pembiayaan musyarakah terus mengalami peningkatan setiap tahunnya pada bank bri syariah dan bank bni syariah. (Bank Muamalat Indonesia, n.d.) Penurunan terjadi hanya pada bank muamalat indonesia. Bank muamalat harus berusaha semaksimal mungkin untuk meningkatkan pembiayaan dengan sistem bagi hasil ini. Hal itu dikhawatirkan akan berpengaruh dengan pendapatan bagi hasil yang akan diperoleh oleh bank. Agar pendapatan bagi hasil optimal, bank harus melakukan berbagai upaya seperti menarik minat masyarakat untuk melakukan pembiayaan musyarakah dengan memberikan infromasi berupa keuntungan yang akan didapat bila menjalankan pembiayaan tersebut. agar pembiayaan musyarakah ini terus meningkat setiap tahunnya.

Penelitian ini diharapkan dapat memberi manfaat bagi berbagai pihak akademisi dan menjadi bahan acuan untuk penelitian selanjutnya yang akan mengambil judul yang sama dengan penelitian ini, dan juga diharapkan dapat menjadi pertimbangan bank umum syariah untuk mengkaji permasalahan yang ada dalam pembiayaan musyarakah dan pendapatan bagi hasil, seperti kurangnya minat masyarakat dalam menjalankan pembiayaan musyarakah sehingga menurunnya perkembangan pembiayaan musyarakah setiap tahunnya.

\section{KAJIAN PUSTAKA DAN PENGEMBANGAN HIPOTESIS}

\section{Pembiayaan Musyarakah}

(Antonio, 2016, p. 90) Musyarakah adalah akad kerja sama antara dua pihak atau lebih untuk suatu usaha tertentu dimana masing-masing pihak memberikan kontribusi dana (atau amal/expertise) dengan kesepakatan bahwa keuntungan dan risiko akan ditanggung bersama sesuai dengan kesepakatan. (Pradja, 2015, p. 160) Pembiayaan musyarakah adalah suatu perjanjian pembiayaan antara bank Syariah dan nasabah, dimana bank syariah menyediakan sebagian dana usaha Sebagian lainnya disediakan oleh 
mitra usaha (mudharib). Dalam hal ini, bank syariah ikut serta dalam manajemen usaha tersebut. Kesepakatan tentang pembagian keuntungan dan kerugian ditanggung Bersama sesuai dengan pangsa pembiayaan masing-masing dengan memakai syarat dan ketentuan bagi hasil.

Maka dari teori-teori tersebut dapat disimpulkan bahwa pembiayaan musyarakah merupakan pembiayaan dalam Syariah yang berprinsip bagi hasil dimana masing-masing pemilik modal menyediakan dana untuk membiayai suatu kegiatan usaha tertentu, lalu keuntungan dibagi sesuai dengan kesepakatan dan kerugian dibagi sesuai dengan porsi dana masing-masing pemilik modal.

\section{Pendapatan Bagi Hasil}

(Antonio, 2016, p. 204) Pendapatan adalah kenaikan kotor dalam asset atau penurunan dalam liabilitas atau gabungan dari keduanya selama periode yang dipilih oleh pernyataan pendapatan yang berakibat dari investasi yang halal, perdagangan, memberikan jasa, atau aktivitas lain yang bertujuan meraih keuntungan, seperti manajemen rekening investasi terbatas.

(Antonio, 2016) Bagi hasil adalah suatu sistem pengelolaan dana dalam perekonomian islam yakni pembagian hasil usaha antara pemilik modal dan pengelola modal.

(Nurhayati \& Wasilah, 2015, p. 146) Prinsip bagi hasil merupakan aturan yang digunakan sebagai dasar pembagian hasil usaha adalah laba bruto (gross profit) bukan total pendapatan usaha (omzet).

\section{Jenis-jenis akad bagi hasil}

Prinsip yang digunakan bank syariah pada system pembiayaan nya yaitu akad musyarakah dan akad mudharabah. Berikut ulasan tentang akad bagi hasil yaitu:

1. Akad Musyarakah

(Ikit, 2015) Musyarakah menurut Fatwa DSN No. 08/DSN-MUI/IV/2000 adalah pembiayaan berdasarkan akad kerja sama antara dua pihak atau lebih untuk suatu usaha tertentu, dimana masing-masing pihak memberikan kontribusi dana dengan ketentuan bahwa keuntungan dan risiko akan ditanggung bersama sesuai dengan kesepakatan.

2. Akad Mudharabah

(Ikit, 2015) Menurut Fatwa DSN No. 07/DSN-MUI/IV/2000 Tentang pembiayaan mudharabah adalah akad Kerjasama suatu usaha antara dua pihak dimana pihak pertama (malik, shahibul maal, Lembaga keuangan syariah) menyediakan seluruh modal, sedang pihak kedua (amil, mudharib, nasabah) bertindak selaku pengelola dan keuntungan usaha dibagi antara kedua pihak sesuai kesepakatan yang dituangkan dalam kontrak.

\section{Hipotesis Penelitian}

Berdasarkan hasil penelitian terdahulu oleh Zaenudin dan Erlina Y (2013) menunjukkan hasil Ho ditolak dan Ha diterima, dimana variabel pembiayaan musyarakah berpengaruh secara parsial terhadap pendapatan bank syariah. Pada penelitian Triana (2019) pembiayaan musyarakah menjadi salah satu faktor untuk mendapatkan pendapatan bagi hasil pada bank syariah. Maka berdasarkan hipotesis dalam penelitian dahulu diatas, dalam penelitian ini dibuat hipotesis sebagai berikut:

Ho : Diduga tidak terdapat pengaruh pembiayaan musyarakah terhadap pendapatan bagi hasil.

Ha: Diduga terdapat pengaruh pembiayaan musyarakah berpengaruh terhadap pendapatan bagi hasil.

\section{METODE PENELITIAN}

Dalam penelitian metode yang digunakan oleh peneliti ini yaitu metode penelitian kuantitatif dengan pendekatan asosiatif. (Sugiyono, 2017) Metode asosiatif digunakan untuk penelitian untuk meneliti seberapa besar pengaruh pembiayaan musyarakah terhadap pendapatan bagi hasil. Dalam penelitian ini populasi nya adalah laporan keuangan triwulan pada 3 bank umum syariah di Indonesia yaitu penelitian dilakukan pada bank muamalat indonesia, bank bni syariah, bank bri syariah periode 2017-2019 dan sampel yang digunakan berjumlah 36 laporan keuangan triwulan pada 3 bank umum syariah periode 2017-2019. Teknik sampling yang digunakan adalah nonprobability sampling dengan teknik sampling jenuh dimana seluruh populasi dijadikan sampel. Teknik analisis data yang digunakan meliputi uji normalitas,uji heteroskedastisitas, uji regresi linier sederhana, uji t, dan uji koefisien determinasi. Uji normalitas digunakan untuk melihat apakah data yang digunakan berdistribusi normal 
atau tidak. Lalu uji heteroskedastisitas untuk melihat apakah data menyebar atau tidak. Uji regresi linier sederhana dilakukan untuk menghasilkan output yang meyakinkan untuk dianalisis lebih lanjut, Uji hipotesis sangat penting dilakukan karena untuk mengetahui seberapa besar pengaruh variabel independen terhadap variabel dependen.

\section{HASIL DAN PEMBAHASAN}

\section{UJI ASUMSI KLASIK} Uji Normalitas

Tabel 2

Hasil Uji Normalitas

\begin{tabular}{|l|l|r|}
\hline \multicolumn{2}{|c|}{ One-Sample Kolmogorov-Smirnov Test } \\
\hline \multicolumn{2}{|c|}{} & \multicolumn{2}{|c|}{ Unstandardized Residual } \\
\hline $\mathrm{N}$ & Mean & .0000000 \\
\cline { 2 - 4 } $\begin{array}{l}\text { Normal } \\
\text { Parameters }\end{array}$ & Std. Deviation & 295522.14285729 \\
\hline Most & Absolute & .089 \\
Extreme & Positive & .089 \\
\cline { 2 - 4 } Differences & Negative & -.087 \\
\hline Test Statistic & & .089 \\
\hline Asymp. Sig. (2-tailed) & $.200^{\mathrm{c}, \mathrm{d}}$ \\
\hline
\end{tabular}

Dalam pengambilan keputusan uji normalitas adalah dikatakan bahwa terdistribusi normal apabila nilai signifikansinya $>0,05$ dan jika nilai signifikansinya $<0,05$ maka data tidak terdistribusi normal. Berdasarkan uji normalitas yang telah dilakukan menggunakan Kormogorov-Smirnov Test dapat diketahui bahwa data penelitian yang digunakan berdistribusi normal. Hal tersebut dapat dilihat dari tabel diatas, bahwa nilai asymp sig 0,200 $\geq 0,05$ yang berarti data penelitian berdistribusi normal. Maka dapat disimpulkan bahwa data sampel pada penelitian layak untuk digunakan.

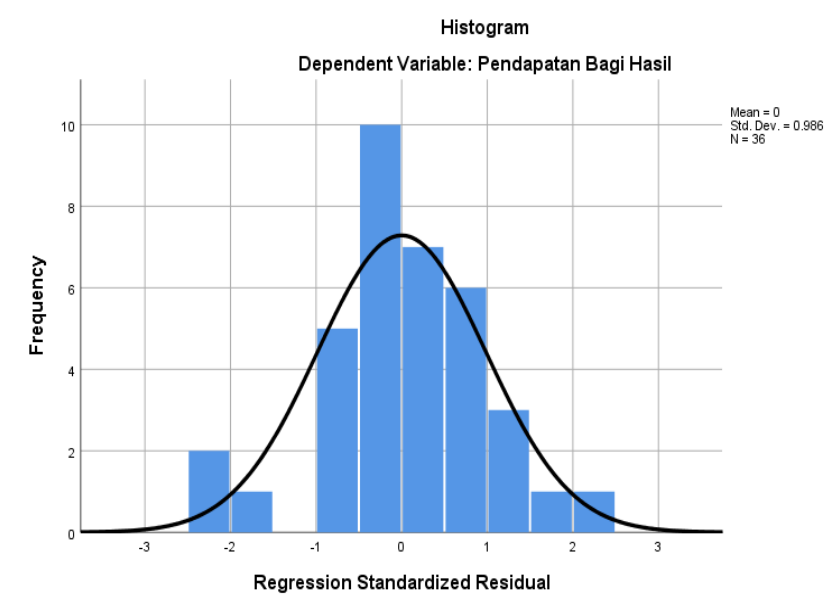

Gambar 1

Histogram

Berdasarkan uji normalitas menggunakan grafik histogram diatas, menunjukkan bahwa kurva berbentuk lonceng ini tidak condong ke kiri maupun condong ke kanan. Yang berarti dapat disimpulkan bahwa data pada penelitian berdistribusi normal. 


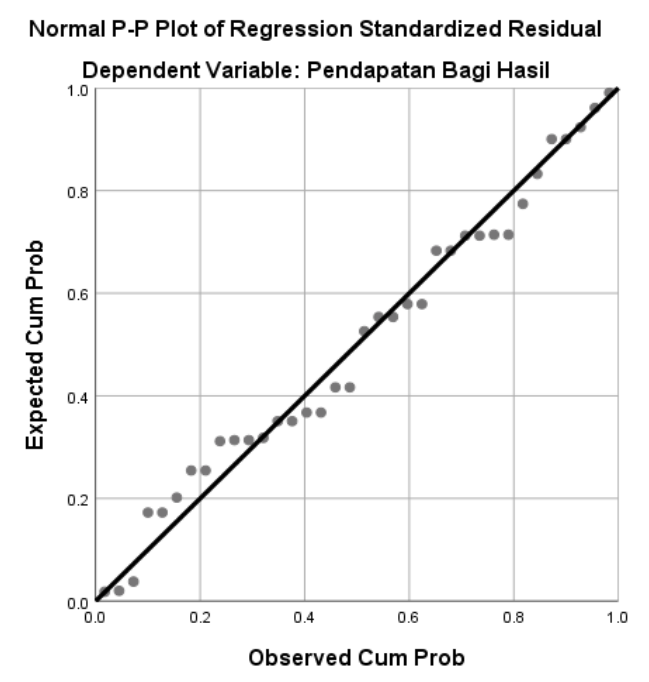

Gambar 2

P-PLOT

Berdasarkan gambar grafik P-Plot, menunjukkan bahwa keseluruhan data penelitian menyebar disekitar diagonal dan mengikuti arah garis diagonal. sehingga dapat disimpulkan bahwa model regresi yang digunakan layak untuk melakukan pengujian karena telah memenuhi asumsi normalitas.

\section{UJI HETEROSKEDASTISITAS}

(Werdiningsih et al., 2020) Uji heteroskedastisitas menggunakan scatterplot bertujuan untuk menguji apakah terdapat korelasi antara variabel independen dan variabel dependen. Variabel dikatakan berkolerasi jika memiliki dependensi atau memiliki pengaruh satu sama lain.

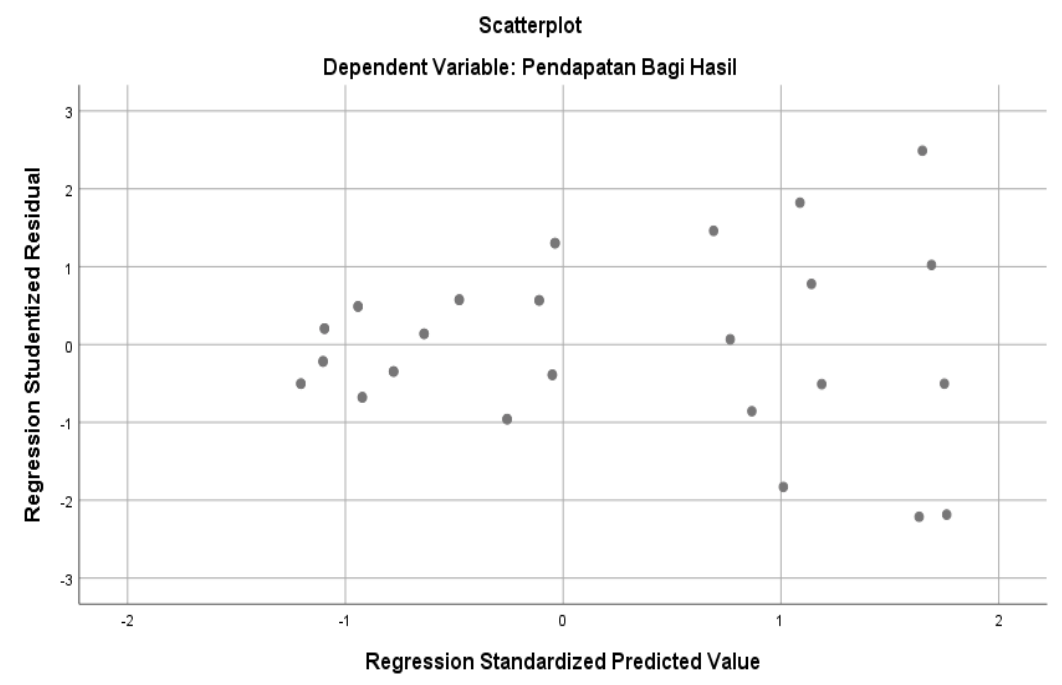

Gambar 3

Scatterplot

Berdasarkan grafik scatterplot diatas, dapat dilihat bahwa titik-titik menyebar secara acak dan tersebar dengan baik diatas maupun dibawah angka 0 pada sumbu pendapatan bagi hasil. Sehingga dapat disimpulkan bahwa model regresi terjadi homoskedastisitas dan tidak adanya gejala heteroskedastisitas pada model regresi. Hal ini menunjukkan bahwa persamaan regresi yang telah memenuhi syarat asumsi heteroskedastisitas. 


\section{ANALISIS REGRESI LINEAR SEDERHANA}

Tabel 3

Analisis Regresi Linier Sederhana

\begin{tabular}{|c|c|c|c|c|c|c|}
\hline \multicolumn{7}{|c|}{ Coefficients $^{a}$} \\
\hline \multicolumn{2}{|c|}{ Model } & \multicolumn{2}{|c|}{ Unstandardized Coefficients } & \multirow{2}{*}{$\begin{array}{c}\text { Standardized } \\
\text { Coefficients } \\
\text { Beta } \\
\end{array}$} & \multirow[t]{2}{*}{$\mathrm{t}$} & \multirow[t]{2}{*}{ Sig. } \\
\hline & & $\mathrm{B}$ & Std. Error & & & \\
\hline \multirow[t]{2}{*}{1} & (Constant) & 114357.569 & 100490.493 & & 1.138 & .263 \\
\hline & $\begin{array}{l}\text { Pembiayaan } \\
\text { Musyarakah }\end{array}$ & .045 & .009 & 670 & 5.269 & .000 \\
\hline
\end{tabular}

Berdasarkan hasil uji regresi linier sederhana pada tabel diatas, diketahui bahwa nilai konstanta B sebesar 114357,569 dan nilai koefisien regresi sebesar 0,045. Nilai konstanta dan koefisien ini dimasukan dalam persama sebagai berikut :

\section{UJI t (Parsial)}

$$
\mathrm{Y}=114357,569+0,045 \mathrm{X} 1+\mathrm{e}
$$

Tabel 4

Uji t

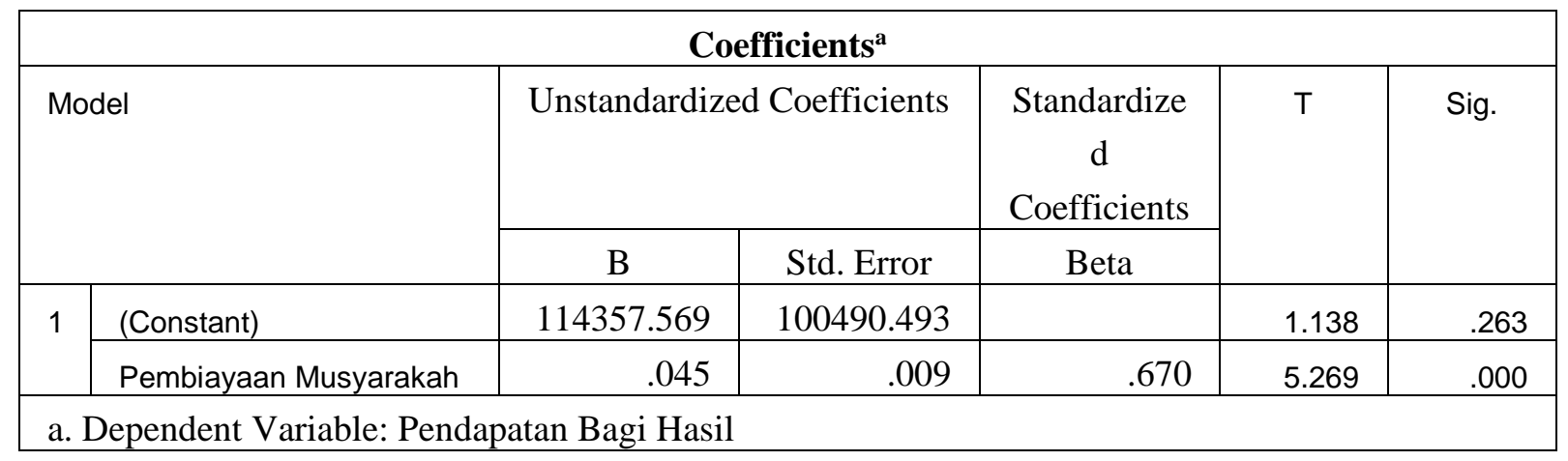

Berdasarkan uji t pada tabel diatas, diketahui bahwa pembiayaan musyarakah berpengaruh terhadap pendapatan bagi hasil. Dimana nilai signifikansi sebesar $0,000<0,05$ yang berarti terdapat pengaruh antara pembiayaan musyarakah terhadap pendapatan bagi hasil.

\section{KOEFISIEN DETERMINASI}

\section{Tabel 5}

Koefisien Determinasi

\begin{tabular}{|l|l|r|r|c|}
\hline \multicolumn{5}{|c|}{ Model Summary $^{\mathbf{b}}$} \\
\hline Model & $\mathrm{R}$ & R Square & $\begin{array}{c}\text { Adjusted R } \\
\text { Square }\end{array}$ & $\begin{array}{c}\text { Std. Error of the } \\
\text { Estimate }\end{array}$ \\
\hline 1 & $.670^{\mathrm{a}}$ & .450 & .433 & 299836.563 \\
\hline
\end{tabular}

a. Predictors: (Constant), Pembiayaan Musyarakah

b. Dependent Variable: Pendapatan Bagi Hasil

Berdasarkan tabel koefisien determinasi diatas, menunjukkan bahwa nilai koefisien determinasi (Kd) sebesar 0,450 atau sama dengan $45,0 \%$, nilai yang dihasilkan ini sama dengan bila menggunakan rumus $\mathrm{Kd}=\mathrm{R}^{2} \mathrm{x} 100 \%$. Sehingga dapat disimpulkan bahwa pembiayaan musyarakah memiliki pengaruh 
sebesar 45,0\% terhadap pendapatan bagi hasil pada tiga bank umum syariah di Indonesia, dan sisanya sebesar $55,0 \% \%$ dipengaruhi oleh faktor lainnya yang tidak diteliti pada penelitian ini oleh penulis.

\section{PEMBAHASAN}

Pada hasil pengujian uji t variabel pembiayaan musyarakah (X1) dengan nilai signifikansi $0,000<0,05$. Dengan itu dapat disimpulkan bahwa $\mathrm{Ho}_{2}$ ditolak $\mathrm{Ha}_{2}$ diterima, yang berarti terdapat pengaruh antara variabel pembiayaan musyarakah terhadap pendapatan bagi hasil. Berdasarkan penelitian dan uji hipotesis dengan uji t menggunakan SPSS, bahwa variabel pembiayaan musyarakah memiliki nilai signifikansi sebesar $0,000<0,05$. Dengan itu dapat disimpulkan bahwa Ho ditolak Ha diterima, yang berarti terdapat pengaruh antara variabel pembiayaan musyarakah terhadap pendapatan bagi hasil.

Dengan berpengaruh positifnya pembiayaan musyarakah terhadap pendapatan bagi hasil. Berdampak pendapatan bagi hasil meningkat setiap tahunnya, hal tersebut dapat dilihat pada laporan keuangan manajemen bank syariah, seperti pada BRI Syariah tahun 2018 membukukan pendapatan bagi hasil sebesar Rp724,57 miliar atau 8,11\% meningkat Rp54,365 miliar dibanding tahun 2017 sebesar Rp670,20 miliar. Hal ini terjadi karena BRI Syariah mengalami peningkatan pada pembiayaan berbasis bagi hasil sebesar Rp8,23 triliun tumbuh 27,94\% dari tahun 2017 sebesar Rp6,24 triliun. Salah satu faktor peningkatan tersebut terdapat pada investasi musyarakah komersil yang naik $45,13 \%$. Hal tersebut menunjukan bahwa masyarakat memiliki minat yang tinggi dalam melakukan pembiayaan musyarakah ini. Bank harus terus meningkatkan kinerja agar pembiayaan dengan sistem bagi hasil ini terus mengalami peningkatan setiap tahunnya. Agar dapat terus berpengaruh terhadap pendapatan bagi hasil pada bank.

Dalam penelitian (Suaidah, 2020) pembiayaan musyarakah berpengaruh terhadap laba bersih. Dimana pada penelitian ini menunjukkan nilai signifikansi uji t sebesar $0,026<0,05$. Yang berarti dapat disimpulkan bahwa terdapat pengaruh antara pembiayaan musyarakah terhadap laba bersih bank umum syariah. Dalam penelitian (Zaenudin \& Erlina, 2013) pembiayaan musyarakah berpengaruh terhadap pendapatan bank syariah. Dimana pada penelitian ini menunjukkan nilai signifikansi uji t sebesar 0,012 $<0,05$. Yang berarti terdapat pengaruh antara pembiayaan musyarakah terhadap pendapatan bank syariah. Dalam penelitian (Sirat et al., 2018) pembiayaan musyarakah berpengaruh terhadap ROA. Dimana pada penelitian ini menunjukkan nilai t hitung sebesar $-2,569$ dan nilai signifikansi sebesar 0,013. Nilai tersebut lebih besar dibandingkan dengan t-tabel 2,009. Yang berarti 0,013<2,099 dan $\mathrm{p}<$ 0,05 , sehingga dapat disimpulkan bahwa pembiayaan musyarakah berpengaruh terhadap ROA.

\section{KESIMPULAN}

Berdasarkan hasil penelitian dapat disimpulkan bahwa pembiayaan musyarakah berpengaruh positif dan signifikan terhadap pendapatan bagi hasil pada 3 bank umum syariah di indonesia periode 2017-2019. Artinya bila pembiayaan musyarakah terus dilakukan maka akan bertambahnya pendapatan bagi hasil pada bank.

\section{SARAN}

1. Saran teoritis dengan melakukan lebih banyak menggunakan laporan keuangan pada bank syariah lainnya, agar penelitian lebih akurat karena setiap bank syariah memiliki berbagai kondisi yang berbeda.

2. Saran praktis pada penelitian ini bank syariah harus memberikan banyak informasi mengenai akad musyarakah ini kepada masyarakat agar mereka berminat untuk melakukan pembiayaan musyarakah sehingga pendapatan bagi hasil pada bank meningkat.

\section{REFERENSI}

Antonio, M. S. (2016). Bank Syariah Dari Teori Ke Praktik. Gema Insani.

Bank Muamalat Indonesia. (n.d.). Laporan Tahunan: Penguatan Ekosistem Bisnis Syariah. 1-639.

Ikit. (2015). Akuntansi Penghimpunan Dana Bank Syariah (Zuhri (ed.)). DEEPUBLISH.

Nugroho, G. W., Kartini, T., Sudarma, A., Martaseli, E., Nurodin, I., Muchlis, C., Suwiryo, D. H., \& Eriswanto, E. (2019). Panduan Penelitian Skripsi 2019 (I. Ismatullah (ed.)). Cinta Buku Media.

Nurhayati, S., \& Wasilah. (2015). Akuntansi Syariah Di Indonesia. Salemba Empat. 
Pradja, J. S. (2015). AKUNTANSI KEUANGAN SYARIAH Teori \& Praktik. Pustaka Setia Bandung.

Sabrina, \& Majid, M. S. A. (2019). Mengapa Pembiayaan Berbasis Bagi Hasil Rendah Di Perbankan Syariah? (Suatu Kajian Menggunakan Pendekatan Grounded Theory). Jurnal Ilmiah Mahasiswa Ekonomi Islam, 1(1), 51-70.

Sirat, A. H., Bailusy, M. N., \& Ria, S. La. (2018). Pengaruh Pembiayaan Mudharabah, Musyarakah, Murabahah Dan Ijarah Terhadap Profitabilitas Bank Umum Syariah (Bus) Yang Terdaftar Di Otoritas Jasa Keuangan (Ojk). Jurnal Manajemen Sinergi (JMS), 5(2), 1-35.

Suaidah, I. (2020). Pengaruh pembiayaan mudharabah dan pembiayaan musyarakah terhadap laba bersih bank umum syariah tahun 2014-2017. 3, 17-27.

Sugiyono. (2017). Metode Penelitian. Alfabeta Bandung.

Triana, L. (2019). PENDAPATAN BAGI HASIL DAN PERLAKUAN AKUNTANSINYA PADA BANK SYARIAH (Studi Kasus pada PT Bank Muamalat Indonesia Cabang Serang). Banque Syar'i : Jurnal Llmiah Perbankan Syariah, 3(1), 01. https://doi.org/10.32678/bs.v3i1.1912

Werdiningsih, I., Nuqoba, B., \& Muhammadun. (2020). DATA MINING Menggunakan Android, Weka, SPSS. Airlangga Uniersity Press.

Zaenudin, \& Erlina, Y. (2013). Pengaruh Pembiayaan Mudharabah dan Musyarakah Terhadap Pendapatan Bank Syariah. 1(77). 